\title{
THE ROLE OF LAND TENANCY IN RICE FARMING EFFICIENCY IN UPLAND KARST MOUNTAINOUS GUNUNGKIDUL INDONESIA
}

\author{
KHOTIMAH, Y. K. ${ }^{1}-$ ANTRIYANDARTI, E. ${ }^{2 *}-$ SUPARDI, S. ${ }^{2}$ \\ ${ }^{1}$ Master Program of Agribusiness, Postgraduate School, Universitas Sebelas Maret \\ Jl Ir Sutami 36A, Kentingan, Surakarta 57126, Indonesia \\ ${ }^{2}$ Study Program of Agribusiness, Faculty of Agriculture, Universitas Sebelas Maret \\ Jl Ir Sutami 36A, Kentingan, Surakarta 57126, Indonesia \\ *Corresponding author \\ e-mail:ernoiz_a@staff.uns.ac.id \\ (Received $6^{\text {th }}$ Jun 2019; accepted $11^{\text {th }}$ Oct 2019)
}

\begin{abstract}
The land area of paddy has decreased every year. Karst as one of the most extensive dry land areas in Indonesia is used to raise paddy as well. This study aims to determine the role of land tenancy in rice farming efficiency and the determining factors of the efficiency of rice farming in the karst mountainous Gunungkidul. The research is located in karst mountainous area of Gunung Sewu, Gunungkidul. This study uses the stochastic frontier analysis with cost function approach. The result shows that the estimated parameter of land rent, price of urea fertilizer, labor wage, and production are significantly correlated with the cost production of rice farming. In addition, land tenancy plays an important role in increasing the efficiency of rice farming in the karst mountainous Gunungkidul. Farmers prefer to lease land in the long term between 1-4 years due to the fact that the price offered is cheaper. Other factors that improve the efficiency of rice farming are the number of household members and farm size, while the household head age decreases the efficiency of rice farming.
\end{abstract}

Keywords: paddy, land tenancy, stochastic frontier analysis, cost function, farm size

\section{Introduction}

Indonesia is classified as the third largest rice consumer in the world with an average of 38.41 million tons per year (Ministry of Agriculture, 2016). Rice as the primary food of the Indonesian people with a population of 258, 705 million in 2016 (Central Bureau of Statistics Republic of Indonesia, 2017). Compared to other food commodities, per capita rice consumption is the highest (Central Bureau of Statistics Republic of Indonesia, 2017) with an average of $98.01 \mathrm{~kg} /$ year (Ministry of Agriculture, 2016).

Due to high consumption of rice, Indonesian rice production is not able to meet the demand and the commodity must be imported. During the 1983-2016 period the value of trade's balance of rice became deficits every year (Ministry of Agriculture, 2016). Even though Indonesia is also the third largest paddy producing in the world $(8.11 \%)$ reaching 77.29 million tons (FAO, 2018). The cultivated of rice in Indonesia are lowland paddy and dry paddy.

The increasing productivity of dry paddy is higher than lowland paddy. During the period of 2010-2013 dry paddies reached 3.43\%/year (Irawan, 2015). The success of increasing productivity of paddy on dry land is not only because of increasing land area, but also caused by technological innovation and an intensification program approach. In fact, the land area has decreased every year. In the period of 2010-2016 the total area of 
agricultural land was decreased by more than 3,202,560.55 ha (Ministry of Agriculture, 2015a, 2017).

Rice farmers in Indonesia actually have economies of scale which is being able to enlarge their farmland (Antriyandarti and Fukui, 2016). However, the average land area is still stagnant around 0.3 hectares. This is due to several obstacles in the process of enlarging (Antriyandarti and Fukui, 2016; Antriyandarti, 2018). The recommended alternative policy to expand the land is by increasing land liquidation. According to Antriyandarti (2018) liquidation of agricultural land in Indonesia has not gone well, only a small percentage of farmers are renting out their land. Land liquidation is a condition of land market through rent (lease) or sale. In rural Java, land is part of social status and inheritance that must be maintained. Sale of farmland is very rare and in many cases when sale does happen, it is a difficult process.

The potential of availability agricultural land in Indonesia is quite large and has not been utilized optimally. There are 95.81 million hectares which are potential for agriculture, with 70.59 million hectares of which are located on dry land (Ministry of Agriculture, 2015b). Karst is one of the most extensive dry land areas in Indonesia. Indonesia classified as a country that uses the largest karst waters in the world (Margat and Gun, 2013; Younos et al., 2019). The karst region in Indonesia is also the largest karst region in Southeast Asia (Clements et al., 2006). Indonesian karst is estimated at \pm 15.4 million hectares (National Development Planning Agency, 2016). One of the karstic areas that become a prototype of karst in tropical regions in Indonesia is karst Gunungsewu, Gunungkidul (Adji et al., 1999).

Gunung Sewu is one of two UNESCO Global Geoparks in Indonesia (UNESCO, 2017). Gunung Sewu as a karst terrain that is geologically, geomorphologically and hydrogeologically shows unique phenomena. It is a classic tropical karst landscape in the south central part of Java Island well-known in the world, and dominated by limestone. Typical formation of "conical hills" is the formation of a series of small hills which are estimated to be 40,000 hills it can be called "gunung sewu". The Javanese word "sewu" translates into "thousand".

Geology of Gunungsewu expresses tracks of tectonic, erosion, denudation, and deposition occurred since Miocene epoch. Gunungsewu displays a specific Tropical landform, characterized by the existence of hills, closed depressions, and caves (Kusumayudha et al., 2015). Groundwater systems in this area are dominated by gaps resulting from dissolution which cause dry conditions on the surface. So that for agricultural production is less optimal. This condition causes low crop productivity and causes high poverty (Retnowati et al., 2014; Central Bureau of Statistics of Yogyakarta Province, 2017).

According to (Liu et al., 2017) agricultural land rent increases productivity from households with low productivity to high productivity. The land leasing market to bring land to more productive uses while at the same time providing development of rural non-agricultural economies (Deininger and Jin, 2003; Deininger et al., 2006). According to Zhang (2008), the tenancy increases efficiency in agriculture, because households that acquire land use it more productively. On the other hand (Roger, 1998), productivity and efficiency have a relationship with each other, namely productivity growth includes changes in efficiency and increased efficiency can increase productivity. If technically the production process is carried out inefficiently, it will have an impact on the failure to realize maximum productivity. Therefore, the factors that cause the efficiency of rice farming need to be known. This paper has significant 
contributions. This is the first study that aims to determine the role of land tenancy on the efficiency of rice farming in the Gunungkidul Karst Mountainous. Then, the recommendation of this study will be useful for Indonesian government to set the alternative policies and strategies to enlarge farmland in Java which has the largest contribution to the national rice production. Expanding farmland on Java Island would improve the national productivity of rice.

\section{Materials and methods}

This research was conducted in the karst mountainous, Gunungsewu area Gunungkidul district located in the coordinates $110^{\circ} 19^{\prime} 48^{\prime \prime}-110^{\circ} 50^{\prime} 24^{\prime \prime}$ BT and 752’48”- 8॰12’36” LS (see Fig. 1). Gunungsewu karst region is a prototype of karst in the tropical region in Indonesia (Kusumayudha et al., 2015; Adji et al., 1999). The focus of the study was carried out in the Girusubo sub-district where the area is in the south which occupies a large part of the Gunungsewu karst region (Regional Development Planning Agency of Gunungkidul, 2013; Tjia, 2013; Retnowati et al., 2014).

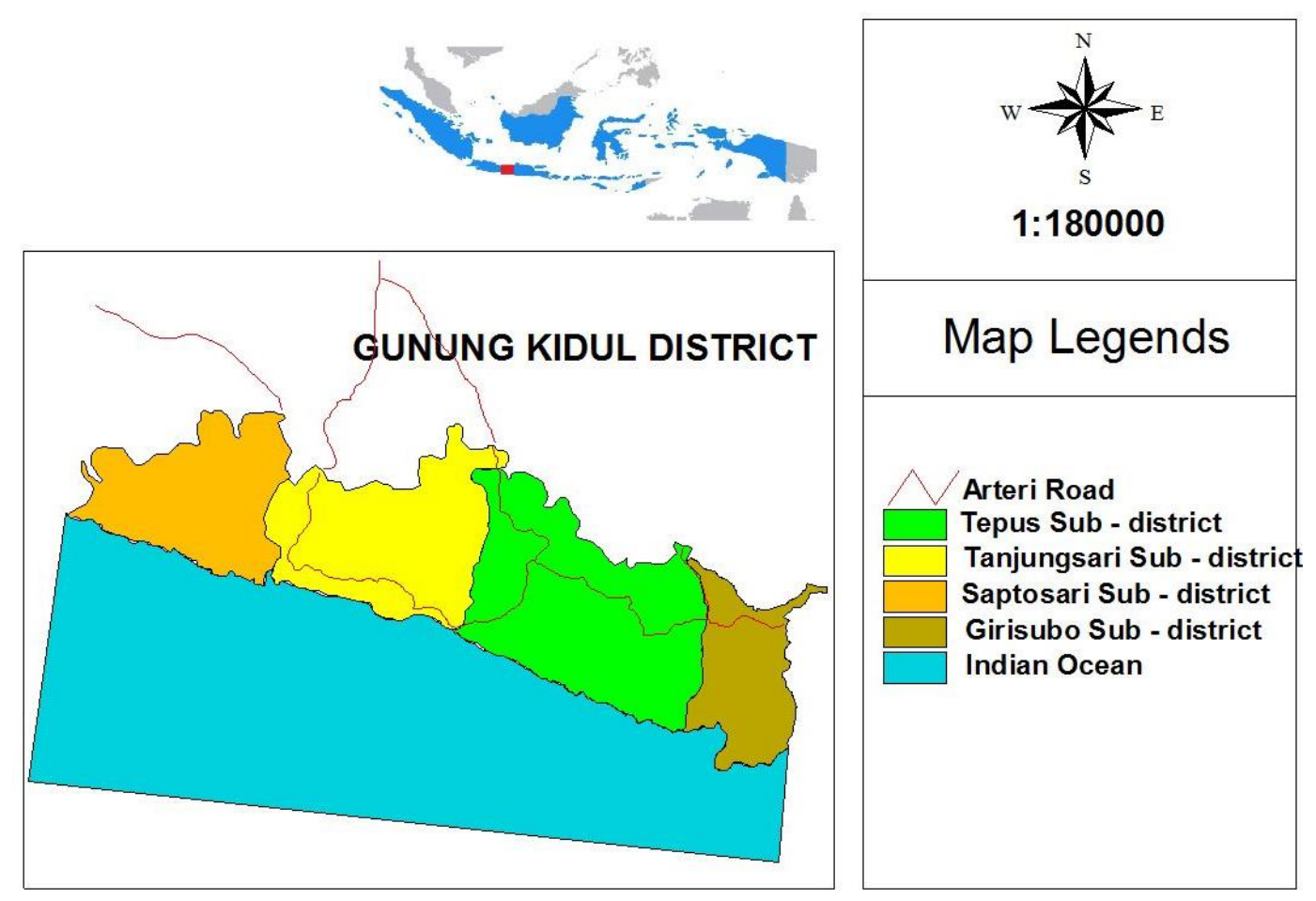

Figure 1. The Gunung Sewu Karst Area in Gunungkidul District

The farmers in the study area use karst groundwater as groundwater system. The characteristics of this karst region are influenced by secondary porosity (groundwater flow through dissolving gaps) which causes water to enter the underground flow system and cause dry conditions on the ground (Ford and William, 2007; Cahyadi et al., 2013). So that rice cultivation is not optimal. Because of that reason, the cultivation of rice uses rain to get water or can be called rainfed rice. Where it can only be planted once a year when the rainy season arrives. It cannot be planted for other planting seasons since rice requires a lot of water. 
The soil condition in this karst region is classified as dry. So it causes the condition of infertile land that has an impact on agricultural cultivation in this region is less optimal (Regional Development Planning Agency of Gunungkidul, 2013). The income of farmers in the Gunungkidul karst area is very small due to the land in this area is not fertile and only relies on rainwater. This condition causes low crop productivity and causes high poverty (Retnowati et al., 2014; Central Bureau of Statistics of Yogyakarta Province, 2017). The survey was conducted in July 2018. The research was collected from household farmers selected as samples using the in-depth interview method with a structured questionnaire prepared. The questionnaire contains characteristic of respondents, farming system, inputs and outputs of crops, farmland liquidation. The sample used was 60 households of rice farmers using the random sampling method.

One method for estimating a production frontier using such data is to envelop the data points using an arbitrarily-chosen function. This approach was used Cobb-Douglas production frontier of the form:

$$
\operatorname{Ln} q_{i}=x_{i} \alpha-u_{i} i=1, \ldots, I
$$

where $q_{i}$ represents the output of the $i$-th firm; $x_{i}$ is a $\mathrm{K} \times 1$ vector containing the logarithms of inputs; $\alpha$ is a vector of unknown parameters; and $w$, is a non-negative random variable associated with technical inefficiency.

The production frontier $(E q .1)$ is deterministic insofar as $q_{i}$ is bounded from above by the non-stochastic (i.e., deterministic) quantity $\exp \left(\mathrm{x}_{i} \alpha\right)$. A problem with frontiers of this type (and with the DEA frontier) is that no account is taken of measurement errors and other sources of statistical noise - all deviations from the frontier are assumed to be the result of technical inefficiency. An obvious solution to the problem is to introduce another random variable representing statistical noise. The resulting frontier is known as a stochastic production frontier. The stochastic frontier production function model of the form

$$
\operatorname{Ln} q_{i}=x_{i} \alpha+v_{i}-u_{i}
$$

Equation 2 is identical to the model Equation 1 except we have added a symmetric random error, V/, to account for statistical noise. Statistical noise arises from the inadvertent omission of relevant variables from the vector $x_{i}$, as well as from measurement errors and approximation errors associated with the choice of functional form. The model defined by Equation 2 is called a stochastic frontier production function because the output values are bounded from above by the stochastic (random) variable $\exp \left(\mathrm{x}_{\mathrm{i}} \alpha+\mathrm{v}_{\mathrm{i} .}\right)$. The random error $\mathrm{v}$, can be positive or negative and so the stochastic frontier outputs vary about the deterministic part of the model, $\exp \left(\mathrm{x}_{i} \alpha\right)$.

These important features of the stochastic frontier model can be illustrated graphically. To do so it is convenient to restrict attention to firms that produce the output qt using only one input, $x$. In this case, a Cobb-Douglas stochastic frontier model takes the form:

$$
\operatorname{Ln} q_{i}=\alpha_{0}+\alpha \ln x_{i}+v_{i}-u_{i}
$$

This study uses a stochastic frontier analysis with cost function approach. The method of the stochastic frontier cost function which is a derivative of the Cobb- 
Douglas production function. The cost function of the stochastic frontier according to (Kumbhakar et al., 2015; Coelli et al., 2005) the equation is as follows:

$$
\ln C=\alpha_{0}+\alpha_{1} \ln P x_{1}+\alpha_{2} \ln P x_{2}+\alpha_{3} \ln P x_{3}+\alpha_{4} \ln P x_{4}+\alpha_{5} \ln P x_{5}+\left(v_{i}-u_{i}\right)
$$

$C=$ Total cost production (USD)

$P x_{1}=$ Land rental (USD/ha)

$P x_{2}=$ Labor wage (USD/HOK)

$P x_{3}=$ Seed price $(\mathrm{USD} / \mathrm{kg})$

$P x_{4}=$ Fertilizer price $(\mathrm{USD} / \mathrm{kg})$

$P x_{5}=$ Production $(\mathrm{kg})$

$U_{i}=$ Farmer specific characteristics related to cost inefficiency

$V_{i}=$ Statistical disturbance term

Variable total cost production expresses cost as a function of input prices and outputs (Coelli et al., 2005). Examples of variable costs include the costs associated with the purchase of inputs such as seeds, fertilizers, wages of labor, land rent, herbicides, insecticides, and so on (Debertin, 2004). Land Rental is costs incurred by farmers to rent land during one crop rotation be counted in (USD/ha). Labor wages is costs incurred to pay labor used in the production process for various types of activities farming system, from land preparation to post-harvest during one crop rotation be counted in (USD/HOK). Price of seeds, fertilizers is costs incurred to buy seeds and fertilizers used in a crop rotation be counted in (USD/kg). According to Antriyandarti (2015) seed prices, labor costs, tractor fees, land rental, irrigation costs significantly correlated with total cost in some rice producing areas in Indonesia. Cost is the total cost including land cost, labor cost and material cost, materials include seed, water, fertilizer, chemicals, mulch and other agricultural production materials and services (Liu et al., 2017).

To identify the determinants of cost inefficiency, we estimate the following regression Equation 2.

$$
U_{i}=\delta_{0}+\delta_{1} Z_{1}+\delta_{2} Z_{2}+\delta_{3} Z_{3}+\delta_{4} Z_{4}+\delta_{5} Z_{5}+e
$$

$\mathrm{U}_{\mathrm{i}}=$ Cost inefficiency effects

$Z_{l}=$ Land tenure (if rented land $=1$; others $=0$ )

$Z_{2}=$ Number of household member (people)

$Z_{3}=$ Education of household head (years)

$Z_{4}=$ Age of household head (years)

$Z_{5}=$ Farm size (ha)

$\mathrm{e}=$ Error term

Efficiencies are observed among rice farmers to examine factors that explain why some farmers are more efficient than others. The source of inefficiency in rice farming concerns the characteristic of the farm and farmers (Villano and Fleming, 2004). Furthermore, efficiency will imply to raise the productivity (Okoruwa, et al., 2006). The base for determining this variable is because of that variable influencing technical inefficiency must be a farmer characteristic or socioeconomic. Variable of age, education, family member, kind of land, location of land, land tenure, off farm occupation, farm size plot significantly correlated with inefficiency in some rice producing areas in Indonesia (Antriyandarti, 2015). Fukui et al. (2002) that the 
production efficiency under tenancy land is not lower than that of the owned land. Variable of renting land, renting out land, head age, education, agricultural labor, block size, soil fertility, landform significantly correlated with cost inefficiency components in wheat and maize in Gansu, China (Liu et al., 2017). Variable of farmers' age, frequency of participation in counseling, frequency of participation in training, the role of institution, farming system management significantly correlated with inefficiency in organic rice farming in Boyolali Indonesia (Sudrajat et al., 2017). Variable of age, education, training, farm size has effect on inefficiency in rice farmers in Bangladesh (Rahman, 2013).

\section{Results and discussion}

Efficiency of cost is the possibility of the minimum cost ratio with the level of specific inefficiencies to the actual total cost (Coelli et al., 2005; Kumbhakar and Lovell Knox, 2000). Therefore, efficiency of cost is defined as the percentage of achieving production costs with best practices. Thus, estimation of the cost efficiency index is calculated from the frontier analysis function. Table 1 presented the input prices, production and potential determinants of cost inefficiency in the study area.

Table 1. Input prices, production and potential determinants of cost inefficiency

\begin{tabular}{c|c|c|c|c}
\hline Variable & Min & Max & Mean & $\begin{array}{c}\text { Amount } \\
\text { (percentage) }\end{array}$ \\
\hline Total cost (USD) & 150.697 & 545.494 & 309.926 & \\
Land rent (USD/ha) & 59.653 & 596.525 & 230.077 & \\
Labor wage (USD/HOK) & 3.190 & 4.052 & 3.686 & \\
Seed (USD/kg) & 0.522 & 0.969 & 0.699 & \\
Fertilizer (USD/kg) & 0.137 & 0.164 & 0.153 & \\
Production (kg/ha) & 200.000 & $2,700.000$ & 967.000 & \\
Family member (person) & 1.000 & 7.000 & 3.183 & \\
Education of household head (year) & 0.000 & 16.000 & 7.066 & \\
Age of household head (year) & 23.000 & 85.000 & 53.500 & \\
Farm size (ha) & 0.250 & 1.000 & 0.450 & \\
\hline Land Tenure: \% of land is HH's owned land & & & & \\
- All owned (person) & & & & $28(47 \%)$ \\
- Mixed (owned and rent) (person) & & & & 0 \\
- All rent (person) & & & & $32(53 \%)$ \\
\hline
\end{tabular}

HOK = Workday of labor

This study uses the Cobb Douglas stochastic frontier cost function model. Cost function analysis is carried out to examine the factors that influence the total cost of rice farming in study area. In the initial cost function it is suspected that there are five variables, namely production, land rent, seed price, fertilizer price, and labor wage. The result can be shown by Table 2 .

The estimation results illustrate the best performance of the respondent farmers at the level of existing technology. This study uses half model with heteroscedasticity, so the standard error is the white standard error (Baum, 2006). The coefficient of all variables is positively significant, except the seed price is negative but not significant. Thus, the results are mostly plausible and consistent with the theory. The estimated parameter of land rent, fertilizer price, production and labor wage are positively significant to the 
total production cost. While, the estimated parameter of seed price is not significant the total production cost. This is in line with the Rachmat (1985) variable of seed prices do not have a significant effect on total costs and coefficients are negative. Antriyandarti (2015) seed price variables had no effect on the total cost production and coefficient values were negative in rice farming in North Sumatra, West Java and Central Java.

Table 2. Estimation of Cobb-Douglas frontier cost function

\begin{tabular}{c|c|c}
\hline Variable & Coefficient & S.E \\
\hline Land rent & $0.102^{*}$ & 0.053 \\
Labor wage & $1.272^{* *}$ & 0.555 \\
Seed price & $-0.060^{\mathrm{ns}}$ & 0.096 \\
Fertilizer price & $0.819^{*}$ & 0.467 \\
Production & $0.259^{* * *}$ & 0.050 \\
Constant & -7.282 & 7.206 \\
Number of obs & 60 & \\
Log likelihood & 20.7156 & 0.015 \\
Sigma_v & 0.171 & 0.208 \\
Sigma_u & 0.004 & 0.005 \\
Sigma2 & 0.029 & 0.210 \\
Lamda & 0.025 & \\
\hline
\end{tabular}

*Significant at $10 \%$ level; $* *$ significant at $5 \%$ level; $* * *$ significant at $1 \%$ level, ${ }^{\text {ns }}$ not significant

Variable of production is positively significant to total cost production at $1 \%$ level. An increase in rice production by $1 \%$ lead to increase the total cost production of rice farming by $0.25 \%$. Variable of land rent has positive effect on the total cost production of rice farming at $10 \%$ level, with a coefficient of 0.102 it is mean that an increase in land rent by $1 \%$ lead to increase the total cost by $0.1 \%$. In addition, the frontier cost elasticity of the variables of fertilizer and labor is 0.81 and 1.27 , respectively. This result is consistent with Antriyandarti (2015).

The result of the determinants of cost inefficiency is presented in Table 3. The estimated parameter of land tenure as dummy variable is negatively significant to the inefficiency of rice production cost at 5\% level. The status of 'tenant' land will decrease inefficiency compared to the status of non-tenant land. In other words, land tenancy will increase the efficiency of rice farming in the karst mountainous, Gunungkidul. This is highly related to the behavior of farmers. The farmer who rent land has higher motivation to take care for their land so that productivity is higher compared to the owned land farmers. The tenant farmers strive to manage production in a professional manner and are receptive to new technology; therefore, they can improve their production and increase their income. This result is in accordance with Antriyandarti (2015) that land rent has a positive effect on the efficiency of rice farming costs in most parts of Indonesia. This finding is also consistent with Mailena et al. (2014) and the result in Central Java by Fukui et al. (2002) that production efficiency on rented land is not lower than that of the owner's own land.

Tenancy of land in the karst mountainous Gunungkidul, originated from the farmers who rent land to other farmers, the land of the village treasury managed by village officials to fund the construction of infrastructure or village needs, and the land which is right of the village officials to compensate for their salary called "tanah lungguh". The contract of land tenancy term is ranging from 1-4 years. If the farmer rents in the long run the price offered is cheaper. This finding is the main highlight of this study. Land 
tenancy plays an important role on improving the efficiency of rice farming in karst mountainous Gunungkidul which is an unproductive area with a high poverty rate. Poverty alleviation effort in this area is very urgent (Antriyandarti et al., 2018). The improvement of efficiency of rice farming would improve rice farm income. Thus, the poverty in karst mountainous Gunungkidul can be reduced.

Table 3. Potential determinants of cost inefficiency

\begin{tabular}{c|c|c}
\hline Variable & Coefficient & Std. Err \\
\hline Land tenure & $-0.074^{* *}$ & 0.031 \\
Household member & $-0.095^{* *}$ & 0.041 \\
Education & $-0.017 * *$ & 0.006 \\
Age & $0.020^{* *}$ & 0.007 \\
Farm size & $-0.110^{* * *}$ & 0.002 \\
Constant & $0.522^{*}$ & 0.276 \\
\hline F-stat & & $52.57 * * *$ \\
Number of observations & & 60 \\
$\mathrm{R}^{2}$ & & 0.792 \\
\hline
\end{tabular}

*Significant at $10 \%$ level; **significant at $5 \%$ level; ***significant at $1 \%$ level

The estimated parameter of number of household member is negatively significant to the inefficiency of rice farming at 5\% level. The larger number of household members will reduce the inefficiency of rice farming in the karst mountainous Gunungkidul. This indicates that efficiency will increase if the number of households increases. This finding is contrast with Antriyandarti (2015) which states that the number of family members influences the increase in inefficiency of rice farming in West Java and North Sumatra, Indonesia. The rice farming in Gunungkidul is dominated by the use of family labor for land preparation, transplanting, fertilization, weeding, and harvesting.

The education of household head is also negatively significant to inefficiency of rice farming. It is suggested that the higher education can manage rice farming more efficiently. This is in line with the (Antriyandarti, 2015; Rahman, 2013; Sudrajat et al., 2017) that education has a positive effect on the cost efficiency of rice farming. The education is an important variable that can improve efficiency. Conditions in the field prove that farmer education is still low, so that it becomes a problem in efficiency. Therefore, this finding has policy implementation for government to improve education and managerial skills of farmers. Meanwhile, the variable of age is positively significant to inefficiency of rice farming. This indicates that the older the farmer, the greater inefficiency of rice farming or in other word, the younger farmer will produce more efficient farming. This finding is contrast with Antriyandarti (2015). The younger household head in the study area suggests more adaptable to accept and implement the new innovation technology of rice farming that can achieve high efficiency. Thus, farmer regeneration is strongly needed, particularly family member in the farm household. However, degeneration in agricultural sector is serious problems in most countries since young people are uninterested in farming or in rural futures.

The estimated coefficients of farm size are significantly negative to inefficiency of rice farming in karst mountainous Gunungkidul. This shows that the larger farm size will increase the efficiency of rice farming (Antriyandarti, 2015). 


\section{Conclusion}

The results show that land tenancy and farm size increases the efficiency of rice farming in the karst mountainous, Gunungkidul. This is much related to the behavior of farmers where renting land have the motivation to care for their land so that productivity is higher compared to farmers who own their own land. Land tenancy has important role in increasing efficiency and improving farmland liquidation in dryland area. Farm size can be enlarged by improving land tenancy system. Farmers in the study area need to enlarge their farm size by leasing land from others because rice farmers in upland Gunungkidul are not willing to sell their land. This prompted the government to facilitate leasing of land in rural areas to increase rice production. Moreover, local government can facilitate transaction in rental market and promote farmland liquidation. Enlarging farm size not only increases efficiency but also increases farm household income. Therefore, the poverty in the karst mountain region in Gunungkidul can be reduced (Antriyandarti, 2018).

\section{REFERENCES}

[1] Adji, T., Haryono, E., Woro, S. (1999): Karst area and its development prospects in Indonesia. - Seminar PIT IGI in Universitas Indonesia, 26-27 Oktober 1999 (in Indonesian).

[2] Antriyandarti, E. (2015): Competitiveness and cost efficiency of rice farming in Indonesia. - Journal of Rural Problems 51(2): 74-85.

[3] Antriyandarti, E. (2018): Constraints of farm size enlargement in the rice sector of Central Java: A case study. - Bulgarian Journal of Agricultural Science 24(6): 949-958.

[4] Antriyandarti, E., Fukui, S. (2016): Economies of scale in Indonesian rice production: an economic analysis using PATANAS data. - Journal of Rural Problems 52(4): 259-264.

[5] Antriyandarti, E., Fajarningsih, R. U., Agustono, Darsono, Marwanti, S., Supardi, S., Sutrisno, J., Ferichani, M., Barokah, U., Rahayu, W., Ani, S. W., Khairiyakh, R. (2018): Poverty alleviation system of dryland farm community in karst mountains Gunungkidul, Indonesia. - IOP Conf. Ser: Earth Environ. Sci. 200: 012062.

[6] Baum, C. F. (2006): An Introduction to Modern Econometrics Using Stata. - Stata Press, Texas.

[7] Cahyadi, A., Ayuningtyas, E. A., Prabawa, B. A. (2013): Urgence of management of effort sanitation water resources conservation in karst area Gunungsewu Gunungkidul Region. - Indonesian Journal of Conservation 2(1): 23-32 (in Indonesian).

[8] Central Bureau of Statistics of DIY Province (2017): Daerah Istimewa Yogyakarta in Figures. - BPS-Statistic of D. I. Yogyakarta Province, Indonesia.

[9] Central Bureau of Statistics Republic of Indonesia (2017): Statistic Year Book of Indonesia 2017. - BPS-Statistics, Indonesia.

[10] Clements, R., Sodhi, N. S., Schilthuizen, M., Ng, P. K. L. (2006): Limestone karsts of Southeast Asia: imperilled arks of biodiversity. - Journal of Bio Science 56(9): 733-742.

[11] Coelli, T. J., Rao, D. S. P., O'Donnell, C., Battese, G. E. (2005): An Introduction to Efficiency and Productivity Analysis. - Springer International Publishing, New York.

[12] Debertin, D. L. (2004) : Agricultural Production Economics. - Pearson Education, New Jersey.

[13] Deininger, K., Jin, S. (2003): Land Sales and Rental Markets in Transition: Evidence from Rural Vietnam Policy Research. - The World Bank, Washington, DC.

[14] Deininger, K., Jin, S., Nagarajan, H. K. (2006): Equity and efficiency impacts of rural land rental restrictions: Evidence from India. - Policy Research, Working Paper 4324, The World Bank, Washington, DC. 
[15] Food and Agricultural Organization (2018): faostat.org. - Accessed on July 29, 2018.

[16] Ford, D., Williams, P. (2007): Karst Geomorphology and Hydrology. - John Wiley \& Sons Ltd, Chichester.

[17] Fukui, S., Hartono, S., Iwamoto, N. (2002): Risk and rice farming intensification in Rural Java. - The Japanese Journal of Rural Economics 4: 32-43.

[18] Irawan, B. (2015): Dynamics of Paddy Rice and Upland Rice Production: Implications for Rice Production Improvement Policies. - In: Pasadaran, E. (ed.) Strengthening Food Self-Sufficiency Capability. Indonesian Agency for Agricultural Research and Development (IAARD) Press, Jakarta, pp. 68-87 (in Indonesian).

[19] Kumbhakar, S. C., Lovell Knox, C. A. (2000): Stochastic Frontier Analysis. - Cambridge University Press, Cambridge.

[20] Kumbhakar, S. C., Wang, H. J., Horncastle, A. P. (2015): Stochastic Frontier Analysis Using STATA. - Cambridge University Press, Cambridge.

[21] Kusumayudha, S. B., Setiawan, J., Ciptahening, A. N., Septianta, P. D. (2015): Geomorphologic model of Gunungsewu Karst, GunungKidul Regency, Yogyakarta Special Territory, Indonesia: the role of lithologic variation and geologic structure. Journal of Geology Resource Eng. 3: 1-7.

[22] Liu, Y., Wang, C., Tang, Z., Nan, Z. (2017): Farmland rental and productivity of wheat and maize: an empirical study in Gansu, China. - Journal of Sustainability (9) 1678: 1-18.

[23] Mailena, L., Shamsudin, M. N., Radam, A., Latief, I. (2014): Rice farms efficiency and factors affecting the efficiency in MADA Malaysia. - Journal of Applied Sciences 14: 2177-2182.

[24] Margat, J., Gun, J. (2013): Groundwater around the World: A Geographic Synopsis. CRC Press, Taylor and Francis Group.

[25] Ministry of Agriculture (2015a): Statistic of Agricultural Land 2011-2014. - Center for Agriculture Data and Information System Secretariat General, Jakarta.

[26] Ministry of Agriculture (2015b): Ministry of Agriculture's Strategic Plan for 2015-2019. - Government of Indonesia, Jakarta.

[27] Ministry of Agriculture (2016): Outlook for Agricultural Crops for Rice Food Crops. Center for Agriculture Data and Information System Secretariat General, Jakarta.

[28] Ministry of Agriculture (2017): Statistic of Agricultural land 2012-2016. - Center for Agriculture Data and Information System Secretariat General, Jakarta.

[29] National Development Planning Agency (2016): Indonesian Biodiversity Strategy and Action Plan 2015-2020. - NDPA, Jakarta

[30] Okoruwa, V. O., Ogundele, O., Oyewusi, B. O. (2006): Efficiency and productivity of farmers in North Central Nigeria. - Paper presented at the International Association of Agricultural Economists Conference, August 12-18, 2006, Australia.

[31] Rahman, M. C., Siddique, M. A. B., Salam, M. A., Islam, M. A., Al-faisal, M. S. (2013): Assessment of technical efficiency of rice farmers in a selected empoldered area of Bangladesh. - European Journal of Agricultural Sciences 10: 2668-3547.

[32] Regional Development Planning Agency of Gunungkidul (2012): Regional Profile of Gunungkidul Regency. - Regional Development Planning Agency of Gunungkidul, Indonesia.

[33] Retnowati, A., Anantasari, E., Marfai, M. A., Dittmann, A. (2014): Environmental ethics in local knowledge responding to climate change: an understanding of seasonal traditional calendar pranotomongso and its phenology in karst area of GunungKidul, Yogyakarta, Indonesia. - Procedia Environmental Sciences 20: 785-794.

[34] Roger, M. (1998): The definition and measurement of productivity. - The University of Melbourne Institute of Applied Economics and Social Research, Working Paper 9/98.

[35] Sudrajat, I. S., Rahayu, E. S., Kusnandar, K., Supriyadi (2017): Effect of social factors in stochastic frontier profit of organic rice farming in Boyolali. - Bulgarian Journal of Agricultural Science 23(4): 551-559. 
[36] Tjia, H. D. (2013): Morphostructural development of Gunungsewu Karst, Java Island. Indonesian Journal of Geology 8(2): 75-88.

[37] UNESCO (2017): UNESCO global geoparks celebrating earth heritage, sustaining local communities. - www.globalgeopark.org (accessed on January 30, 2019).

[38] Villano, R., Fleming, E. (2004): Analysis of technical efficiency in a rainfed lowland rice environment in Central Luzon Philippines using a stochastic frontier production function with a heteroskedastic error structure. - Working Paper Series in Agricultural and Resource Economics, University of New England.

[39] Wang, H., Riedinger, J., Jin, S. (2015): Land documents, tenure security and land rental development: panel evidence from China. - China Economic Review 36: 220-235.

[40] Younos, T., Schreiber, M., Ficco, K. K. (2019): Karst Water Environment Advances in Research, Management and Policy. - In: Stevanovic, Z. (ed.) Karst Aquifers in the Arid World of Africa and the Middle East: Sustainability or Humanity? Springer International Publishing, Switzerland, pp. 2-40.

[41] Zhang, Q. F. (2008): Retreat from equality or advance towards efficiency? Land markets and inequality in Rural Zhejiang. - Journal of the China Quarterly 195: 535-557. 